\title{
でんぷんとアクリロニトリルとの反応による水溶性誘導体の製造
}

\author{
京都大学工学部 坂 口康義
維化学教室

\section{PREPARATION OF WATER SOLUBLE DERIVATIVES OF STARCH BY REACTION WITH ACRYLONITRILE}

\section{By Yasuyoshi Sakaguchi}

(Department of Textile Chemistry, Faculty of Engineering, Kyoto University, Kyoto, Japan)

Starches were reacted with acrylonitrile in the presence of $\mathrm{NaOH}$. By this reaction cyanoethyl (A) and carboxyethyl (B) ethers of starch were obtained. Derivatives in which B degree was higher than about 0.07 mole/base mole, and B degree/A degree was higher than 1 were soluble in cold water. No water soluble products could be obtained by reaction of starch with formaldehyde.

(Received March 18, 1958)

\section{1. 緒言}

既報に括いで，でんぷんをモノクロル酷酸あるいは エチレンクロルとドリンを用いてエーテル化を行つて， 適当条件下では冷水に溶解する誘尊体が得られることを 認めた。でんぷんをアクリロニトリル(以下AN と略 記）をアルカリの存在下で反応させると，次式に示すよ らにまずシアノエチルエーテルが生成し，これはさらに ケン化を受けて酸フマイドを経てカーボキシェチルエー テルに変る。

Starch $-\mathrm{OH}+\mathrm{CH}_{2}=\mathrm{CHCN} \longrightarrow$ Starch $-\mathrm{O}-\mathrm{CH}_{2}-\mathrm{CH}_{2}-\mathrm{CN}$ $\longrightarrow$ Starch-OH- $\mathrm{CH}_{2}-\mathrm{CH}_{2}-\mathrm{CONH}_{2} \longrightarrow$ Starch-O-CH $-\mathrm{CH}_{2}-\mathrm{COONa}$

セルロースのシアノエチルエーテル化に関しては近年多 数の研究が行われてきている。でんぷんについても若干 の報告があり，適当反応条件下で水溶性誘導体が得られ ることなどが認められている2。しかしながら反広条件 と生成物の組成，水溶性との関俰についてはある詳細 でな報告がないのでここの点に関して实験を行つた。また んら゚んをホルムアルデメイドと加王下で反応させると，

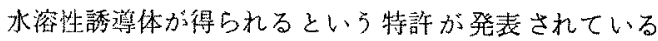
が，この反応について若干の卖駼を行つた。

\section{2. 実験 方 法}

原料としては断りのない限り市販の小菨でんぷんが用 いられたが，ばれいしよでんぷんについても実驗を行つ た。これに $\mathrm{NaOH}$ 水溶液を加觉て十分混和後, AN を 加党て再びよく混和してから，所定温度で反応を行つ
た。反応終了後のペーストはメタノール中に投じて生成 物を沈でんさせ，再沈でん法なとによつて精製後 $60^{\circ} \mathrm{C}$ で乾操した。

生成物の組成は，キエルダール法に上る窒素の定量と 電導度谪定法によるカルボン酸基の定量から, 酸アマイ ドは存在していないと仮定して求めた。また生成物の $15^{\circ} \mathrm{C}$ の水に対与る溶解性を定性的に調べて，ほぼ透明 に溶解するすのを○，かなり溶解するが溶液の濁りの大 きいるのそム，女まり溶解しない子のを×で表わした。

\section{3. 反応液の組成ならびに反応時間の影響}

反応液の組成を広い範囲に変更して，30 3 で各種時 間反心行つて，生成物の組成と水溶性がどのように变 化するかを諯べた。まずでんぶん濃度を一定に保ら， AN と $\mathrm{NaOH}$ の渚度を变えて宾験を行った。これらの 結果を一括すると第 1 表の通りである。この表に叔 て， $\mathrm{AN} と \mathrm{NaOH}$ の濃度はでんぶん 1 基本分子当りの モル数で表わしたが,でんぷん：AN : $\mathrm{NaOH}$ のモル比 が $1: 1: 1$ の場合の重量比は $1: 0.327: 0.247$ である。 またエーテル化度は基本分子当りのモル数で表わした。

第 1 表の結果から次のことが認められる。AN 濃度を 一定にして $\mathrm{NaOH}$ 濃度を高めると，一般に $\mathrm{CN}$ 結合量 は低下してCOONa 結合量は增加する。アルカリ濃度の 低いときは反応時間をある程度以上長くしても， COONa 結合量はあまり大さくならず CN 結合䁷は大して変化し ない。他万アルカリ濃度の高い場合は，ある時間後は時 間とともに CN 結合量は顕著に低下して, COONa 結合 量もかなりの值に達する。しかしながら結合 $\mathrm{CN}$ と 


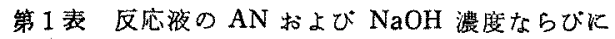
反応時間の影響

(小麦でんタ゚ん $9 \%$ ，反応温度 $30^{\circ} \mathrm{C}$ )

\begin{tabular}{|c|c|c|c|c|c|c|}
\hline \multirow{2}{*}{$\begin{array}{c}\mathrm{AN} \\
\text { 濃度 }\end{array}$} & \multirow{2}{*}{$\mid \begin{array}{c}\mathrm{NaOH} \\
\text { 濃度 }\end{array}$} & \multirow{2}{*}{$\begin{array}{l}\text { 反応時 } \\
\text { 闎，時 }\end{array}$} & \multicolumn{3}{|c|}{ エーテル化度 } & \multirow{2}{*}{ 水溶性 } \\
\hline & & & \multicolumn{3}{|c|}{$\mathrm{CN} \quad \mathrm{COONa} \mathrm{CN}+\mathrm{COONa}$} & \\
\hline 1.8 & 0.5 & 3.5 & 0.780 & 0.015 & 0.795 & $x$ \\
\hline 1.8 & 1.0 & 3.5 & 0.684 & 0.024 & 0.708 & $x$ \\
\hline 1.8 & 2.0 & 3.5 & 0.609 & 0.060 & 0.669 & $x$ \\
\hline 1.8 & 4.0 & 3.5 & 0.474 & 0.114 & 0.588 & $x$ \\
\hline 1.8 & 4.0 & 16 & 0.018 & 0.354 & 0.372 & 0 \\
\hline 1.2 & 0.5 & 3.5 & 0.105 & 0.014 & 0.119 & $x$ \\
\hline 1.2 & 4.0 & 3.5 & 0.342 & 0.114 & 0.456 & $\times$ \\
\hline 1.2 & 4.0 & 16 & 0.000 & 0.243 & 0.243 & 0 \\
\hline 0.6 & 0.25 & 3.5 & 0.324 & 0.018 & 0.342 & $x$ \\
\hline 0.6 & 0.5 & 1 & 0.240 & 0.012 & 0.252 & $x$ \\
\hline 0.6 & 0.5 & 2 & 0.231 & 0.018 & 0.249 & $x$ \\
\hline 0.6 & 0.5 & 3.5 & 0.261 & 0.018 & 0.279 & $x$ \\
\hline 0.6 & 0.5 & 16 & 0.246 & 0.039 & 0.285 & $x$ \\
\hline 0.6 & 0.5 & 90 & 0.255 & 0.066 & 0.321 & $x$ \\
\hline 0.6 & 1.0 & 3.5 & 0.249 & 0.021 & 0.270 & $x$ \\
\hline 0.6 & 2.0 & 3.5 & 0.198 & 0.093 & 0.291 & $x$ \\
\hline 0.6 & 2.0 & 16 & 0.258 & 0.099 & 0.357 & $x$ \\
\hline 0.6 & 2. 0 & 16 & 0.054 & 0.090 & 0.144 & 0 \\
\hline 0.6 & 4.0 & 3.5 & 0.192 & 0.141 & 0.333 & $x$ \\
\hline 0.6 & 4.0 & 16 & 0.000 & 0.204 & 0.204 & 0 \\
\hline 0.25 & 0.5 & 3.5 & 0.198 & 0.017 & 0.215 & $x$ \\
\hline 0.25 & 2.0 & 16 & 0.060 & 0.063 & 0.123 & $\Delta$ \\
\hline 0.25 & 4.0 & 3.5 & 0.129 & 0.120 & 0.249 & $x$ \\
\hline 0.25 & 4.0 & 16 & 0.000 & 0.120 & 0.120 & 0 \\
\hline 0.12 & 0.5 & 3.5 & 0.105 & 0.014 & 0.119 & $x$ \\
\hline
\end{tabular}

COONa の和は支る時間以後は減少して就り， CN が COONa Kタン化される反応の他に，エーテル結合の切 断妿起ることを示している。全ェーテル化度は，反応時 間が比較的長い場合にはアルカリ濃度の高い方が低い。 またアルカリ濃度を一定に保つて AN 濃度を高めると， エーテル化度は堌大するがエーテル化度/AN 使用量の

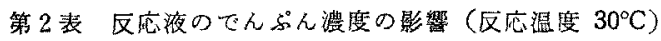

\begin{tabular}{|c|c|c|c|c|c|c|c|c|}
\hline \multirow{2}{*}{$\begin{array}{c}\text { で } \\
\text { ん濃度 } \\
\%\end{array}$} & \multirow{2}{*}{$\begin{array}{l}\text { AN } \\
\text { 濃度 }\end{array}$} & \multirow{2}{*}{$\begin{array}{l}\mathrm{NaOH} \\
\text { 被度 }\end{array}$} & \multirow{2}{*}{$\begin{array}{c}\text { 反底 } \\
\text { 時間] } \\
\text { 時 }\end{array}$} & \multicolumn{4}{|c|}{ エーテル化度 } & \multirow{2}{*}{$\begin{array}{l}\text { 水 } \\
\text { 溶 } \\
\text { 哖 }\end{array}$} \\
\hline & & & & $\mathrm{CN}$ & COONa & $\mathrm{CN}$ & $+\mathrm{COONa}$ & \\
\hline 36 & 0.6 & 0.5 & 3.5 & 50.345 & 0.06 & & 0.423 & $x$ \\
\hline 36 & 0.6 & 0.5 & 16 & 0.283 & 0.08 & & 0.368 & $x$ \\
\hline 54 & 0.6 & 0.5 & 3.5 & 0.165 & 0.08 & & 0.249 & $x$ \\
\hline 54 & 0.6 & 0.5 & 16 & 0.135 & 0.11 & & 0.249 & $\triangle$ \\
\hline 36 & $|0.25|$ & 0.5 & 16 & 0.110 & 0.07 & & 0.182 & $\Delta$ \\
\hline 36 & 0.12 & 0.5 & 16 & 0.017 & 0.06 & & 0.077 & $x$ \\
\hline 54 & 0.12 & 0.5 & 16 & 0.019 & 0.08 & & 0.102 & $x$ \\
\hline
\end{tabular}

値は低下する。COONa 結合量は，反応洔間の短い間は AN 濃度により大差ないが，反応時間が長くなるとAN 灌度とともに增大する。

次にでんぶん濃度を変更して反応を行つた。実䮖の条 件ならびに結果は第 2 表に示す道りであり，反応物質の

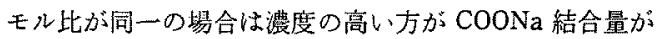
大さく，水溶性倸導体が得られやすい傾向が琶められ る。

\section{4. 反応温度の影響}

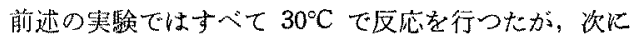
$50^{\circ} \mathrm{C}$ で反応を行つて，反応の様子を $30^{\circ} \mathrm{C}$ の場合と比較 した。これらの結果住第3表に示す通りである。 $30^{\circ} \mathrm{C}$ の場合と比べると、シアノェチルェーテル化の速度もこ のエーテルのタン化速度もとも江大きく，水港性侤遵体 が得られやすい。反応浴の組成扣よび反応時間が生成物 の組成に及ぼす影響は $30^{\circ} \mathrm{C}$ の場合と同様である。

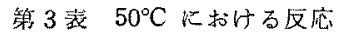
（小麦でんぷ 9\%，*印のみ 36\%)

\begin{tabular}{|c|c|c|c|c|c|c|}
\hline \multirow{2}{*}{$\begin{array}{c}\mathrm{AN} \\
\text { 濃度 }\end{array}$} & \multirow{2}{*}{$\mid \begin{array}{c}\mathrm{NaOH} \\
\text { 濃度 }\end{array}$} & \multirow{2}{*}{$\begin{array}{l}\text { 反応時 } \\
\text { 間，時 }\end{array}$} & \multicolumn{3}{|c|}{ エーテル化度 } & \multirow{2}{*}{ 水溶性 } \\
\hline & & & \multicolumn{3}{|c|}{$\mathrm{CN}$ COONa $\mathrm{CN}+\mathrm{COONa}$} & \\
\hline 1.8 & 0.5 & 3 & 0.558 & 0.036 & 7.594 & $x$ \\
\hline 1.8 & 3.0 & 3 & 0.117 & 0.201 & 0.318 & 0 \\
\hline 1.2 & 0.5 & 3 & 0.465 & 0.045 & 0.510 & $x$ \\
\hline 1.2 & 3.0 & 3 & 0.099 & 0.231 & 0.333 & 0 \\
\hline 0.6 & 0.5 & 1 & 0.246 & 0.075 & 0.321 & $x$ \\
\hline 0.6 & 0.5 & 3 & 0.312 & 0.081 & 0.393 & $x$ \\
\hline 0.6 & 0.5 & 16 & 0.000 & 0.081 & 0.081 & 0 \\
\hline $0.6^{*}$ & 0.5 & 16 & 0.069 & 0.078 & 0.147 & 0 \\
\hline 0.6 & 1.0 & 3 & 0.216 & 0.111 & 0.327 & $x$ \\
\hline 0.6 & 1.0 & 16 & 0.000 & 0.120 & 0.120 & 0 \\
\hline 0.6 & 2.0 & 3 & 0.087 & 0.162 & 0.249 & 0 \\
\hline 0.6 & 2.0 & 16 & 0.000 & 0.177 & 0.177 & 0 \\
\hline 0.6 & 3. 0 & 1 & 0.198 & 0.108 & 0.306 & $x$ \\
\hline 0.6 & 3.0 & 3 & 0.051 & 0.258 & 0.309 & 0 \\
\hline 0.6 & 3.0 & 16 & 0.000 & 0.168 & 0.168 & 0 \\
\hline $0.25 *$ & 0.25 & 16 & 0.068 & 0.061 & 0.129 & $x$ \\
\hline 0.25 & 0.5 & 3 & 0.129 & 0.066 & 0.195 & $x$ \\
\hline 0.25 & 0.5 & 16 & 0.060 & 0.054 & 0.114 & 0 \\
\hline $0.25^{*}$ & 0.5 & 16 & 0.021 & 0.069 & 0.090 & $\Delta$ \\
\hline 0.25 & 3.0 & 3 & 0.048 & 0.141 & 0.189 & $\Delta$ \\
\hline
\end{tabular}

\section{5. 原料でんぷんの種類の影響}

以上の实験に和いては原料として小麦でんぶんを用い た。次に原料でんふんんの影璄を見る目的で，ばれいしよ でんふんを用いて若干の实験を行つた。この際水溶性工 
一テルを得るために必要な $\mathrm{AN} と \mathrm{NaOH}$ の最小使用量 を知ることに主眼を佶いて反応を行って，生成物の水溶 性の及を調べた。实験結果を一括すると第 4 表に示す上 らで，既報の他の誘遵体の場合と同様に，ばれいしょで んぷんを用いる方が小麦でんぷんを原料炕する場合より も水溶性物が得られやすい。ばれいしよでんぶんを原料 にすると，でんぷん $100 \mathrm{~g}$ に対して AN と $\mathrm{NaOH}$ を約 $10 \mathrm{~g}$ ずつ使用することによつて水溶性エーテルを得るこ とができる。

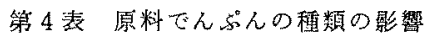

(でえぷん濃度 $36 \%$; 反它 $50^{\circ} \mathrm{C}, 16$ 洔間)

\begin{tabular}{|c|c|c|c|c|c|c|c|c|}
\hline$A N$ 濃 & & 0.6 & 0.25 & 0.25 & 0.25 & 0.15 & 0.15 & 0.15 \\
\hline $\mathrm{NaOH}$ 濃 & 变 & 0.5 & 1.0 & 0.5 & 0.25 & 1.0 & 0.5 & 0.25 \\
\hline 水涭 小 小 & 麦 & 0 & $\Delta$ & $\triangle$ & $x$ & $\Delta$ & $x$ & $x$ \\
\hline ばれい & ᄂょ & 0 & 0 & 0 & 0 & 0 & 0 & $\Delta$ \\
\hline
\end{tabular}

\section{6. 反応生成物の組成と水溶性との関係}

前述の結果上り明らかなよ5亿，反态生成物の水溶性 は結合 $\mathrm{CN}$ 量と COONa 量の兩者によつて規定されて いる。表の結果供ついて，生成物の組成と水溶性の関 係を困示寸ると第1図の通りである。求溶性の領域と不 溶性の領域が多少重なり合つているが，水溶性であるた 污飞必要な大よその組成は, 結合 COONa 量が 0.07 モ

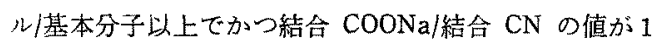
以上であると見なすことができる。な和生成エーテルは 高分子電解䁈であるので，水溶液の粼度は高い。

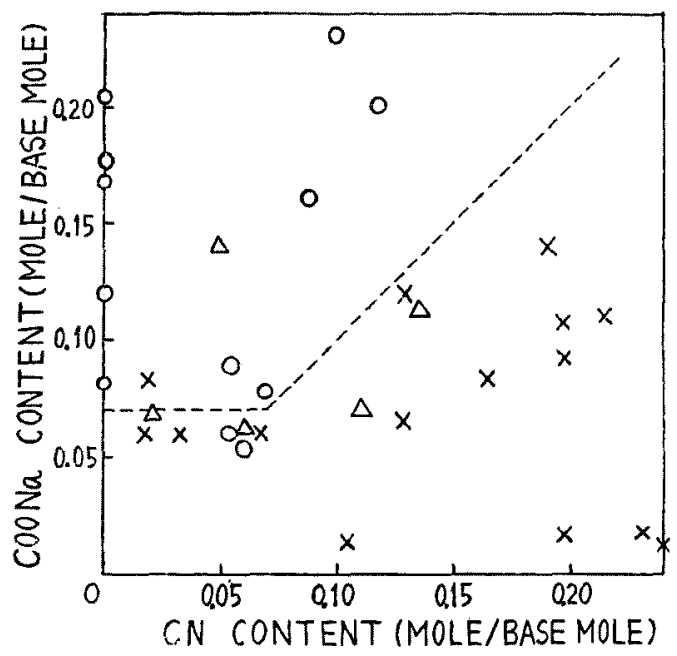

Fig. 1 Relation between composition and solubility of reaction products

\section{7. でんぶんとホルムアルテハイドとの反応}

でんら゚んにホルムアルデッイド(以下FAと略記)を 作用させると，次示す 2 種類の置換が起り，構造 $\mathrm{a}$ が 形成されると本溶性が向上することが期待される。 Starch-O- $\left(\mathrm{CH}_{2} \mathrm{O}\right)_{n} \mathrm{H} \quad$ Starch-O- $\left(\mathrm{CH}_{2} \mathrm{O}\right)_{23}$-Starch (a)

反応方法は他の誘導体の場合々同様であり, 生成物の 結合アルデヒド量（重量\%)を重亜硫酸ソーダ法によつ て定量した。水溶性誘導体が得られやすいばれいしょで

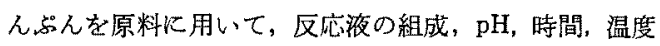
を変更して反応を行つた結果を一括して示すと第 5 表に 示す通りである。

第5㸚でんぷんとホルムテルデハイドと反応

\begin{tabular}{|c|c|c|c|c|c|}
\hline $\begin{array}{c}\text { 反应温眼 } \\
{ }^{\circ} \mathrm{C}\end{array}$ & $\begin{array}{l}\text { でんぷ } \\
\text { 几濃度 } \\
\%\end{array}$ & FA 濃度 & $\mathrm{pH}$ & $\begin{array}{c}\text { 反席特間 } \\
\text { 分 }\end{array}$ & $\mid \begin{array}{c}\text { 結合アル } \\
\text { デイ } \\
\%\end{array}$ \\
\hline 140 & 45 & 15 & 4.5 & 60 & $10.8(0.65)$ \\
\hline 140 & 45 & 15 & 7 & 5 & $5.0(0.29)$ \\
\hline 140 & 45 & 15 & 7 & 15 & $14.9(0.95)$ \\
\hline 140 & 45 & 15 & 7 & 60 & 13.9 \\
\hline 140 & 45 & 15 & 10 & 60 & 12.0 \\
\hline 95 & 45 & 15 & 7 & 15 & $3.6(0.20)$ \\
\hline 95 & 45 & 15 & 7 & 60 & 5.9 \\
\hline 95 & 45 & 5 & 7 & 60 & $2.1(0.12)$ \\
\hline 95 & 30 & 20 & 7 & 120 & 10.3 \\
\hline 95 & 20 & 22 & 7 & 120 & 13.5 \\
\hline 95 & 10 & 26 & 7 & 120 & 13.5 \\
\hline 95 & 10 & 26 & 7 & 30 & 3.9 \\
\hline 70 & 45 & 15 & 7 & 15 & 2.0 \\
\hline 70 & 45 & 15 & 7 & 90 & 9.0 \\
\hline 70 & 10 & 26 & 7 & 90 & 8.0 \\
\hline 40 & 45 & 15 & 7 & 240 & 0.9 \\
\hline
\end{tabular}

（結合アルデハイトの項で括胍内に示した数値は，生 成物の梅造が a $n=1$ であると仮定して算出した救 本分子当りのモル数である。)

第 5 表から明らかなよらに，pH 7 付近で高温で反応を 行うと，比較的短時間内に結合アルデハイド量 $10 \%$ 程 度のるのが得られる。しかしながらこの表に示した生成 物はいずれも冷水にはとんど溶解せず，委心大部分は

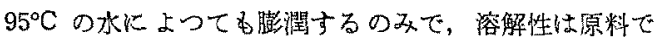
んよ゚んよりも悪い。分子間に b の架橋構造が形成される ことをさけるために、でんぶん濃度を低くして区応を行 つても好結果は得られない。

次に反沈液のアルカリ濃度を前述上りも高めて反応を 行つた。結果の詳縕は略すが，たとえばでんふん澧度を

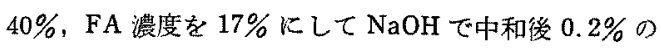
$\mathrm{Na}_{2} \mathrm{CO}_{3}$ を加六た液を $85^{\circ} \mathrm{C}$ で 4 時間反応を行 5 と, 結 
合アルデヒド量は約 1.5\% と中性付近の反応液の場合上 りも著るしく低下する。このような条件で得られな脬導 体怯, $95^{\circ} \mathrm{C}$ の水にはは添溶解するが椧水には溶解しに くいここのように実験籁囲では水溶性物を得ることはで きなかった。たたししでえふんと FA虫高温では中性付 近でる比較的容易に反応寸ることは，興味岕る事実であ ると表えられる。

\section{8. 総括}

でんぶんとアクリロニトリルをアルカリの共存下で反 応を行つた。この祭シアノエチルエーテル化ならびにこ のエーテルのカーボキシニチルエーテルヘのケン化反応 が起る。適当条件ではニトリルと $\mathrm{NaOH}$ 各でんぷん の $10 \%$ 程度使用することによつて，水溶性エーテルが 得られる。生成物が水溶性であるために必要な大よその 組成は，カーポキシエチル化度が 0.07 モ基本分子以
上，カーボキシエチル化度/シアノエチル化度の值が1 以上である。またでんふんとホルムアルデハイドとの反 応们ついても実験を行つた。反応は高温で中性付近でか なりの程度に進行するが，水溶性誘導体を得ることはで きなからた。

御指導を賜つた桜田教授に深く感謝する。

\section{文献}

1) 坂口, 石津; 本誌, 14, 814 (1958)

2) A. D. Houk; Can. P., 434619; Röhm ; Brit.P., 564585; C. H. Bock; U.S.P., 2316128, 2316129; J. H. Greager; J. Soc. Dyers \& Col., 67, 66 (1951)

3) J. Lolkema ; Dutch. P., 60681, 64994, 66492, 67265 ; U.S.P., 2542932, 2562558 ; W. A. van der Meer; Dutch. P., 67471; Dan River Mills; Brit. P., 661376.

\section{ユネスコ・クーポン制度について}

(科学技術者のために)

ユネスコ・クーポン制度とは 為替管理の壁をとり除いて教育, 科学, 文化に関する出版物（学会誌, 学会費等を含む)，映画フイルム，科学資材の輸入を容易にするため，ニネスコが実施している国際的な制 度であつて，この制度に加入している国には上記のものの代金を送るとき，ユネスコ・クーポンをわが国 では円で購入して，これを先方の学会や商社に送ればよいのである。また外国からクーポンで代金を送つ て来たとき，これは円で支执わ机ることになっている。

ユネスコ・クーポンで購入できるもの
(A) 出 版 物
(B) 眏画フィルム
（C）科学資材 (光学機械, 种括上び衡器, 電気測定器, 温度計, 恒温装置, 化学薬品, 実験室用ガラ ス器具など)
詳紐は日本学術振興会（東京都台東区上野公園日本学術会議内）に括問合せ下さい。 